Bulgarian Academy of Sciences. Space Research and Technology Institute.

Aerospace Research in Bulgaria. 33, 2021, Sofia

DOI: https://doi.org/10.3897/arb.v33.e18

\title{
A REVIEW OF EARTH OBSERVATION RESOURCES FOR SECONDARY SCHOOL EDUCATION - PART II
}

\author{
Lachezar Filchev ${ }^{1}$, Ioannis Manakos ${ }^{2}$, Rainer Reuter ${ }^{3}$, Garo Mardirossian', \\ Tsveta Srebrova ${ }^{1}$, Lubomira Kraleva ${ }^{1}$, Dimitar Dimitrov ${ }^{4}$, Kalliroi Marini ${ }^{2}$, \\ Andreas Rienow ${ }^{5}$

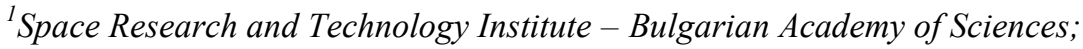 \\ e-mail: lachezarhf@space.bas.bg,G.Mardirossian@space.bas.bg,lkraleva@eeobss.space, \\ Tsveta_Srebrova@space.bas.bg \\ ${ }^{2}$ Information Technologies Institute of the Centre for Research and Technology Hellas, \\ Thessaloniki,Greece; e-mail: imanakos@iti.gr,marini@iti.gr \\ ${ }^{3}$ Carl von Ossietzky Universität Oldenburg, Germany, Germany; \\ e-mail: rainer.reuter@uni-oldenburg.de \\ ${ }^{4}$ National Institute in Geophysics, Geodesy and Geography - Bulgarian Academy of \\ Sciences; e-mail: clgdimi@abv.bg \\ ${ }^{5}$ Ruhr-University, Bochum, Germany; \\ e-mail: andreas.rienow@ruhr-uni-bochum.de
}

Keywords: Secondary school, science education, Earth Observation education, STEM, EO, e-Learning.

\begin{abstract}
This article is a continuation of an overview of the contemporary resources for Earth Observation (EO) education for secondary schools. The themes covered by the sequel are the main EO education initiatives supported by international, EU and national organisations, outreach activities, citizen scientists' projects and free and open source software (FOSS) EO tools. The article elaborates on future prospects of EO resource developments in the education system its relevance for society and its connection with STEM subjects.
\end{abstract}

\section{Introduction}

In the first part of this review, published in Vol. 32 of Aerospace Research in Bulgaria, we covered the worldwide web and e-Learning resources for Earth Observation (EO) education for secondary schools and the main EO education initiatives supported by international, EU and national organisations. It was made clear also by other authors, that despite the developments in the EO for school education $[1,2]$ it is still underutilized [3]. 
The aim of this review, which is Part II of the sequel, is to provide an overview of the available international, regional and national education resources in EO for secondary schools, to identify subjects who are not yet well represented in the curricula but would benefit from using remote sensing in the classroom, and to address several didactic aspects, which could help establish Earth Observation in school.

\section{Data and methods}

Similar to Part I of the review, Part II integrate the material presented at Frascati EO Education Workshop 2014 with other information obtained in the ESA LearnEO! Project and ESA EO Open Science 2016. It is also based on the experience obtained in project Science Education through Earth Observation for High Schools (SEOS) ${ }^{1}$ supported in the $6^{\text {th }}$ FP-EU, FIS, and from the ongoing EO4GEO project (ERASMUS+, EC). The experience gained during EEOBSS project implementation also served as a basis for the review.

\section{Earth observation resources for secondary school education}

Part II of the review we keep on following the logic of Part I when presenting the resources. Thus, the main review findings are presented in alphabetical order of the material producer/provider. In Part II of the review article, EO education activities and resources are organised in the following categories: 1) outreach activities, 2) citizen science, and 3) software and tools.

\section{Outreach activities}

\section{DLR}

The DLR_School_Lab Oberpfaffenhofen [4] is an extracurricular science lab, designed to attract secondary school students to Mathematics, Informatics, Natural Sciences, and Technology (MINT). It has been developed and operated since 2003 and offers thirteen hands-on experiments for secondary school classes, as well as advanced teacher trainings in Physics and Geography.

\section{ESA}

ESA Space Education Resource Offices (ESERO) - so far such offices are established in the following ESA member-states: Belgium, the Czech Republic, Germany, Ireland, Netherlands, Nordic (Denmark, Finland, Sweden, and Norway), Poland, Portugal, Romania, and the United Kingdom. One of these offices is located in Belgium, which has its own website URL: http://www.esero.be and a Facebook page: https://www.facebook.com/ESERO.BELGIE. One of the most

\footnotetext{
1 SEOS project. http://www.seos-project.eu (last date visited 18 March 2021)
} 
interesting and active offices is the ESERO-UK, which has a dedicated website to the Principia mission [5] of the UK member of the International Space Station (ISS) Tim Peake. The space education resource office has its own project activities related to ESA research priorities, among which is EO [6].

The collaboration between ESA and the German Aerospace Centre, DLR (Deutsches Zentrum für Luft- und Raumfahrt) was set up in 2012 to produce 3D videos that will be used in the virtual theatre facilities at ESA. Building on this and the DLR School Lab for schools, a School Lab was organised as part of the IEEE International Geoscience and Remote Sensing Symposium 2012 in Munich. Building on these activities and the education resources developed in the UK, a similar School Lab took place at the ESA Living Planet Symposium in 2013, in collaboration between ESA, DLR, the UK Space Agency (UKSA), the National Centre for Earth Observation (NCEO) and the National Space Centre in Leicester, UK. Similar resources and activities for similar outreach events may be included in future EO symposia and conferences.

New videos for schools and the general public have been created in ESA/ESRIN. This includes an educational video on EO and Volcanoes for schools, produced jointly with the Italian National Institute of Geophysics and Volcanology, INGV (Istituto Nazionale di Geofisica e Vulcanologia).

\section{NASA}

NICE - Innovations in Climate Education (NICE) were a competitive project to promote climate and Earth system science literacy among underrepresented minority groups to science careers and educational opportunities. The three-year project was implemented in partnership with Jackson State University (JSU) and MSU under the cooperative agreement "Strengthening Global Climate Change education through Remote Sensing Application in Coastal Environment using NASA Satellite Data and Models". The goal was to increase the number of high-school and undergraduate students at JSU, a Historically Black University, who are prepared to pursue higher academic degrees and careers in STEM fields [7].

\section{University of Berlin (Freie Universität)}

From 26 February to 22 May 2008, the German Space Agency (DLR) and the Freie Universität Berlin (FU) presented an exhibition on "The new picture of our neighbour Mars" at the university campus of Dahlem in Berlin. Results of the European Mars mission "Mars Express" were presented, in particular images taken by the High Resolution Stereo Camera (HRSC). A guided tour through the images and movies on display was presented to several groups of youngsters: starting from 4 to 15 years. To give a real 3-D impression of the Mars surface, the staff from "the Planetary Sciences and Remote Sensing Group" presented special fly-over animations by using a GeoWall display and by working with anaglyph movies. 
Especially for HRSC data, make use of the press-release data and modify it appropriately so that children of all ages can extract the most important information.

\section{Citizen Scientists (CS) Projects}

ESA is funding four citizen science (CS) projects to test and explore the potential and limits of CS in EO [8]. These pilots look at agriculture support, forest monitoring, land-use classification and air quality.

The Geo-wiki Project [9] is a global network of volunteers who wish to help improve the quality of global land cover maps by adding information on speciesdistribution, habitat, ecosystems and other scientific landuse information.

A Land Cover validation game, developed as a web-based game, was developed by the VGI \& Citizen Science - GEOlab, Polytechnico di Milano (Polymy) [10]. The web-application was successfully tested at a mapping party during the FOSS4G Europe 2015 conference.

\section{EO Software and Tools}

During the past years, numerous software packages and tools have been released, which can be used for EO education in class. Most of them are free and open source software (FOSS), which allows schools and teachers who don't have a dedicated budget for software licences to use free satellite data for their classes. Although their graphical user interface GUI) is developed with a varying level of complexity, they can still be used to perform alone or in combination of basic and even advanced image processing tasks.

The Bilko software [11] was first developed for UNESCO in 1987 to provide free image processing capability for education use. The software has since been updated regularly to keep pace with the developments in remote sensing technology. The LearnEO! The project has extended Bilko's capabilities to include support for data from ESA satellites such as ERS, SMOS and CryoSat, as well as along-track altimeter data from Envisat and Jason-2.

Erdas ER viewer (Hexagon Geospatial (C), available free of charge, can be used to open raster image formats such as TIFF, GeoTiff, IMG, ECW, ERS, ALG, DAT and many more, and are capable of handling large file sizes [12].

ArcGIS for Schools is a recently announced programme for schools by ESRI Inc. The educational programme of the world renown GIS leader was altogether redesigned during past years, including licencing and the professionalisation of the offered courses, through academia and school education. One of the main benefits that ESRI provides during a pandemic is the free use of ArcGIS for schools, which is part of the company social commitment and responsibility. The popular cornerstone product ArcGIS of ESRI is offered for free, 
including the new image processing (including EO data processing) functionality, which is already a part of the suite [13].

ESA toolboxes [14] are designed for professional users of EO data, but are also extensively used in the training of more advanced users, for example through computer exercises for university courses and shorter advanced courses and summer schools. The ESA toolboxes (mostly open source) are freely available from the web and include the Basic ERS \& Envisat (A)ATSR and MERIS Toolbox (BEAM), the Next ESA SAR Toolbox (NEST), a toolbox for the scientific exploitation of polarimetric SAR data (POLSARPRO), the Basic Radar Altimetry Toolbox (BRAT), the GOCE User Toolbox (GUT) and many more. The new satellite data from Sentinel-1, -2 and -3 will be processed using the developed SNAP with Sentinel Toolboxes. Even though more complex for education, they can be easily adopted in class due to its GUI similarities with the ESA education software LEOWorks.

Google Earth [15] has become one of the widely used EO data visualisation tools. Along with the API, the platform allowed many scientists and educators around the world to visualise their own data on a 3D surface. The features, such as street view, geo-tagged imagery, underwater relief attracted many individuals and companies to use the platform to build upon their own ideas. As of the past few years the Google Earth Project released the Professional version free of charge that increased its popularity.

In Europe, one of the earliest and most widely used software tools for image processing with the support of numerous satellite datasets is the Integrated Land and Water Information System (ILWIS) [16]. In late 1984, ITC was awarded a grant from the Dutch Ministry of Foreign Affairs. By the end of 1988, the project resulted in the official release of the DOS version 1.0 of ILWIS. The ILWIS was launched commercially two years later. As of July 1, 2007 ILWIS Open 3.X is available as $52^{\circ}$ North free and open source software (GNU GPL).

Two software packages are indicated by ESA for general education purposes: LEOWorks and Bilko. The LEOWorks [17] is a didactic tool with extensive help pages and an all-inclusive tutorial, allowing students to process satellite imagery and combine them with other geospatial information. The new version is developed in Java, is platform-independent (Windows, MacOS, Linux) and will be released under a General Public License (GPL) ${ }^{2}$. It will include advanced GIS functionality and optical and SAR image processing in a userfriendly environment.

One of the honourable mentions for the EO education legacy software used intensively in the early 2000s is MicroMSI. The MicroMSI for Windows is a remote sensing imagery analysis programme designed for use in introductory courses in remote sensing, developed by the National Geospatial-Intelligence

\footnotetext{
${ }^{2}$ GPL. http://www.opensource.org/licenses/gpl-license.php (last date visited 18 March 2021)
} 
Agency. MicroMSI for Windows is a "public domain programme and can be freely redistributed for non-commercial purposes", after modern terminology freeware. Although not supported, it still features some advanced image processing multispectral image analysis techniques and it supports hypercube visualisation HYDICE and basic spectral analysis [18].

MultiSpec $\bigcirc$ is being developed at the Purdue University, West Lafayette, IN, by David Landgrebe and Larry Biehl from the School of Electrical and Computer Engineering, ITaP and LARS. It results from an on-going multiyear research effort, which is intended to define a robust and fundamentally based technology for analysing multispectral and hyperspectral image data, and to transfer this technology to the user community in as rapid a manner as possible. The results of the research are implemented into MultiSpec and made available to the user community via the download pages. MultiSpec $\mathbb{C}$ with its documentation is distributed free of charge as a desktop online system on the following web-page [19].

One of the first EO software tools used in University education in Asia was Dragon/ips ${ }^{\circledR}$ software developed and marketed by Goldin-Rudahl Systems, Inc. As of 2010, Goldin-Rudahl Systems has agreed that the Open Dragon software, based on Dragon version 5, will be open source for non-commercial use. The Project is currently providing an Open version of the Dragon software which is used worldwide by schools and universities [20]. One of the Open Dragon Project is free lecture materials and hands-on developed and distributed software.

Orfeo ToolBox (OTB) is an open-source project of CNES for a state-of-theart remote sensing. Although a complex one, its free distribution enables educators to use it even in class. It can process high-resolution optical, multispectral and radar images at the terabyte scale. A wide variety of applications are: from orthorectification or pansharpening, all the way to the classification, SAR processing, and more. It includes a fast image viewer, apps callable from Bash, Python or Monteverdi, QGIS, and a powerful C++ API [21].

Quantum GIS (QGIS) is a user friendly free and open source software (FOSS) Geographic Information System (GIS) licenced under the GNU General Public License. The QGIS is an official project of the Open Source Geospatial Foundation (OSGeo). It runs on Linux, Unix, Mac OSX, Windows, and Android and supports numerous vector, raster, and database formats and functionalities [22]. During the last years many educational projects and courses have been intensively relying on QGIS that is due its multifunctionality including GIS and EO capabilities. The wide user community, which produces scripts and extension, leverage its capabilities further, which makes the FOSS GIS and EO software a true alternative for education. 


\section{Discussions and conclusions}

In the Part II of the review we provided a brief overview of outreach activities as well as the citizen science projects and software tools for EO education. With this we hope that we will enable the educators, scientists and student alike, to reach out much easier to the tools and resources needed to jumpstart with EO. However, some of the most pronounced key issues and perspectives with regard to secondary school education were outlined in Part I, which we will not restate here. Rather, we conclude with the self-imposing conclusion of the review that due to many external factors to the secondary school educational system worldwide the change from a non-systemic to a systemic approach in EO education is about to turn into a reality soon. This is mainly due to the existing critical mass of resources, tools, software, as well as projects and initiatives that all lead to a better realisation in the EO community and the policymakers for the professionalisation of the EO. It is well known that the career choice is commonly made during the school years. This is becoming a well-understood fact not only to educators but also to scientists and university staff who always feel the pressure of the need of the well-educated students who are capable of undertaking more and more complex tasks involving EO data and resources. The process of transition is manifold and it also involves many actors on different levels but will inevitably lead to the formulation either of a common education framework for EO education in schools or in the worst case scenario - inclusion of the EO technology in various STEM disciplines taught in class. This is a necessity for times, which also witness an unprecedented inflow of EO data as well as galloping new technology developments and transformations that will build a bridge between education and practice.

\section{Acknowledgements}

The work was carried out as part of "Education in Earth observation for Bulgarian secondary schools - EEOBSS" Project (ESA-PECS for Bulgaria), Contract No. 4000117592/16/NL/NDe concluded between SRTI-BAS and ESA. The views expressed herein do not in any way reflect the official position of the European Space Agency.

\section{References}

1. Merry, C. J., and Stockman, S. Educational outreach activities for Landsat-7. Remote Sens. Environ., 2001, 78, 217-220. DOI:10.1016/S0034-4257(01)00261-9

2. Naumann, S., Siegmund, A., Ditter, R., Haspel, M., Jahn, M., and Siegmund, A. Remote sensing in school - Theoretical concept and practical implementation. In E-Learning Tools, Techniques and Applications; König, G., Lehmann, H., Eds.; ISPRS: Potsdam, Germany, 2009. 
3. Dziob, D., Krupiński, M., Woźniak, E., and Gabryszewski, R. Interdisciplinary Teaching Using Satellite Images as a Way to Introduce Remote Sensing in Secondary School. Remote Sens. 2020, 12, 2868. DOI:10.3390/rs12182868

4. DLR_School_Lab Online. http://www.dlr.de/schoollab/en/desktopdefault.aspx/tabid1708/ (last date visited 18 March 2021)

5. ESERO-UK. https://principia.org.uk/ (last date visited 18 March 2021)

6. European Space Education Resource Office. http://www.esa.int/Education/Teachers_Corner/European_Space_Education_Reso urce_Office (last date visited 18 March 2021)

7. Reddy, S. $\sim$ R. Climate Literacy: STEM and Climate Change Education and Remote Sensing Applications. AGU Fall Meeting Abstracts. 2015. Abstract id. ED33A0934

8. Educeo. http://educeo.net/ (last date visited 18 March 2021)

9. Geo-Wiki: Earth Observation \& Citizen Science. IIASA. http://www.geo-wiki.org/ (last date visited 18 March 2021)

10. http://landcover.como.polimi.it/landcover/\#/ (last date visited 18 March 2018)

11. Bilko Software. http://bilko.org/software.php (last date visited 18 March 2021)

12. Other Producer Products. Hexagon. http://www.hexagongeospatial.com/products/power-portfolio/other-producerproducts/erdas-er-viewer (last date visited 18 March 2021)

13. Schools Mapping Software Bundle. ESRI. 2021. https://www.esri.com/enus/industries/education/schools/schools-mapping-software-bundle (last date visited 18 March 2021)

14. TOOLS \& TOOLBOXES. Earth Online. ESA. https://earth.esa.int/web/guest/picommunity/toolboxes (last date visited 18 March 2021)

15. Google Earth. https://www.google.com/earth/ (last date visited 18 March 2021)

16. ILWIS. http://52north.org/communities/ilwis (last date visited 18 March 2021)

17. LeoWorks. http://leoworks.asrc.ro (last date visited 18 March 2021)

18. Loomer, S. A. Remote sensing education with MicroMSI, In: Geoscience and Remote Sensing Symposium, 2004. IGARSS'04. Proceedings. 2004, 3, 1963-64. IEEE International

19. MultiSpec. https://engineering.purdue.edu/ biehl/MultiSpec/ (last date visited 18 March 2021)

20. Open Dragon. http://www.open-dragon.org/ (last date visited 18 March 2021)

21. Orfeo Toolbox. https://www.orfeo-toolbox.org/ (last date visited 18 March 2021)

22. QGIS. http://www.qgis.org/en/site/ (last date visited 18 March 2021) 


\title{
ОБЗОР НА РЕСУРСИТЕ ПО НАБЛЮДЕНИЕ НА ЗЕМЯТА ЗА СРЕДНОТО ОБРАЗОВАНИЕ - ЧАСТ 2
}

\author{
Л. Филчев, Й. Манакос, Р. Ройтер, Г. Мардиросян, Ц. Среброва, \\ Л. Кралева, Д. Димитров, К. Марини, А. Рийнов
}

\section{Резюме}

Тази статия е продължение на обзора (Част 1) на съвременните ресурси за наблюдение на Земята за средните училища. Темите, обхванати от продължението, са основните образователни инициативи, подкрепяни от международни, европейски и национални организации, дейности по разпространение на резултати, проекти свързани с гражданска наука и инструменти за работа (включително софтуер) със свободен и отворен код (FOSS). В статията се разглежда бъдещето на развитието на ресурсите за наблюдение на Земята в системата на средното образование, което е от значение както за обществото, така и за връзката на наблюдението на Земята със STEM дисциплините. 